\title{
Service Quality and User Satisfaction of Border Area Library Services
}

\author{
Muhammad Nur ${ }^{1}$, Yohanes Fritantus ${ }^{2}$ \\ ${ }^{1}$ Prodi Ilmu Administrasi Negara FISIPOL Universitas Timor, ${ }^{2}$ Prodi Ilmu \\ Pemerintahan FISIPOL Universitas Timor \\ Email: m.nurunimor@gmail.com
}

\begin{abstract}
This study aims to determine the description of the quality of library services at the Regional Libraries in the border area of North Central Timor Regency and to determine the description of the satisfaction of library service users in the border areas in North Central: tangibles, reliability), responsiveness, assurance; and empathy. As for the variable service user satisfaction based on indicators: quality of products/services, emotions; and cost or convenience provided. Data collection was carried out through observation, interview, and documentation techniques. The results showed that the description of the variable quality of library services in the border area of the North Central Timor Regency was quite good through display evidence indicators tangibles, reliability, responsiveness, assurance, empathy. As for the description of service user satisfaction variables based on indicators: quality of products/services; not satisfactory, it is accrued that they are still using the manual system in services at the District Library Office of the Border District. North Central Timor; as for other indicators emotion; and the cost or convenience provided is sufficient or satisfactory.
\end{abstract}

Keywords: Library quality; border area; user satisfaction

\section{INTRODUCTION}

Libraries certainly have a very strategic role in building a civilization in society (Ismail \& Darwis, 2016; Niswaty et al., 2020) borders, namely as a reliable reference source or can be trusted amid difficult access to information technology in border areas plus access to information technology-based information whose references are sometimes unclear. Through the library, it will certainly encourage reading interest as well as the attractiveness of the community/service users in accessing knowledge (Ahmad \& Abawajy, 2014; Miyashita, 1997). Moreover, if the library can provide a quality service that satisfies the public or its users, the library must be the most accurate source of information amid today's onslaught of digital media. (Hack-Polay, 2011; Hull et al., 2008; Sun \& Yuan, 2012). In the digital era with the development of existing information technology systems, libraries are increasingly required to provide sophisticated, up-to-date services so that they can adapt to existing IT conditions and developments. It seems that libraries that do not adapt to people's needs will be left behind.

Libraries, which used to be one of the sources of information reference containing various collections and library materials, now there are many news media or information sources based on IT, internet technology and mobile phones which are almost owned by every individual who wants to access information quickly so that each individual has There are many choices in accessing information, where everyone can freely access all available sources of information. Today's users prioritize easy access, up-to-date information, easy and fast with the use of internet media (Baldonado et al., 1997; Hassanain \& Al Ashwal, 2005; Reviewed et al., 2011)

Copyright (C) 2021 Universitas Negeri Makassar. This is an open access article under the CC BY license (http://creativecommons.org/licenses/by/4.0/) 


\section{Jurnal Administrare: Jurnal Pemikiran Ilmiah dan Pendidikan Administrasi Perkantoran Volume 8 Issue 1, January-June 2021. Pages 77-86}

Along with the development of the digital era of information technology, it is a challenge for the existence of libraries in adjusting all existing developments (Lovasz et al., 2014; Maurya, 2011; Theng et al., 2011). It is no longer enough that libraries are only able to prepare the quality of book sources or references desired, but also how to make it easier for users or the public to access reference sources or knowledge and prepare various other convenience services.

The challenge of libraries as a means of accessing information sources is also tested by adjusting to the times and in today's era. Science and technology at this time have experienced developments in various fields especially technology, communication, and information (Bates \& Gawande, 2003; Taylor \& Todd, 1995; Venkatesh et al., 2003). These various advantages have had a negative influence on the minimal number of visitors to the library. Various advantages of libraries that may not be replaced are existing sources of information that can be referenced from the sources, be it books, journals, articles, and others.

Various studies also explained that many aspects can be obtained from the library itself. One of them in sociological studies, namely the process of interaction between people in the library certainly cannot be replaced by the sophistication of existing information. (Prasetywan: 2014) plus various sources of information that cannot be obtained outside the library can be found in the library collection. Therefore, with the various ease of access to information nowadays, it is not enough to eliminate the role of libraries as a source of information. By considering the various advantages of the libraries above and also the progress or standard of living of the people in each region also varies. Even in various places such as in areas far from the city center, such as digital information media cannot be accessed easily evenly. This is the reason for the existence of libraries to be encouraged in achieving accurate and inexpensive information. Also, no matter how sophisticated the technology is, the role of libraries cannot be avoided. Various studies have also explained that many aspects can be obtained from the library itself.

The Regional Library is one of the libraries provided that is owned and managed by the district/city government as a tangible manifestation of the existence of the local government siding in increasing reading interest and public awareness in increasing people's knowledge. Good regional libraries which have various conveniences and conveniences are certainly very possible conducted by the Regional Government in optimizing the excellence of the Regional Libraries. The more sophisticated and better the Regional Libraries that are owned by the Regency/City Government, the more it indicates the Government's concern for knowledge and awareness of the community. The convenience and ease of access to various reference sources for regional libraries will be a stimulus for people to want to visit the Regional Libraries.

This is no exception for Regional Libraries in the Border Area of the Republic of Indonesia. Border areas are areas that often get less attention from both central and district/city governments in improving the quality and comfort of users of regional library services. The most basic thing that is deemed not optimal from a Regional Library is the inadequate availability of books plus other facilities and infrastructure that are very unequal with Regional libraries in other districts and cities. The location which is far from the city center is, of course, a separate reason so that it is far from the government's attention. Therefore, the Government needs to pay attention and provide strengthening to Regional Libraries both in terms of infrastructure and facilities as well as human resources so that the disparity in the quality of Regional Libraries in cities and other border areas is not too unequal. 
One of the Regional Libraries located in the Border Area is the Regional Library of North Central Timor Regency (TTU Regency), East Nusa Tenggara Province. The location of the North Central Timor Regency is on Timor Island, which is a district bordering the land and sea territory of the Democratic Republic of Timor Leste and bordering the sea with Australia. The regional library of North Central Timor Regency as a regional library located in the Border Region is a source of reference for the people of TTU Regency to access references and sources of information in the Regional Libraries in border areas.

\section{METHOD}

The research design used is a descriptive qualitative research design that aims to describe the quality of regional library services, and pictures of the satisfaction of service users at the Regional Library of the border region of North Central Timor Regency. This research was conducted at the North Central Timor District Library and Archives Office, North Central Timor Regency which is in the border area. The description of the variable quality of regional library services is seen from indicators: tangibles, reliability, responsiveness, assurance; and empathy. As for the description of service user satisfaction, variables are based on indicators: quality of products/services; emotions; and ost or convenience provided. Data collection techniques are observation, interviews, and documentation. Data analysis uses descriptive statistical analysis.

\section{RESULT AND DISCUSSION}

\section{Quality of Regional Library Services in North Central Timor Regency}

From the research results, namely the collection of data on the quality of blood library services in North Central Timor Regency, it can be seen from the indicator indicators: tangibles, reliability, responsiveness, assurance; and empathy. As for the description of the research results obtained as follows:

\section{Tangibles}

From the results of observations and interviews in the field, it is found that the evidence of the appearance of the library in the border area of the North Central Timor Regency Library and Archives Service is quite good in terms of appearance both outside the building and indoors where on the outside of the building there is a parking lot for visitors to the regional library. it's just not equipped with good enough security such as the presence of guards (security) besides that the name board of the Library Service is also worn out which should be replaced. The display in the part of the library room has been equipped with a reading room and a visitor service section, a storage area for goods. However, some of the shelves used in storing books are old and worth replacing, but this has not been fully realized. This was revealed by one of the staff of the Regional Library Office of the District. North Central Timor Regency said that "every year we try to always make improvements to the remaining products of books, reading materials as well as other facilities and infrastructure such as shelves and tables for reading. However, because the budget allocation is limited in nature, of course, it cannot be fully fulfilled by us, we carry out a priority scale of each use of the existing budget. The appearance of the building also still uses a limited building which should be expanded to increase capacity and also because of the complexity of the work. " 


\section{Jurnal Administrare: Jurnal Pemikiran Ilmiah dan Pendidikan Administrasi Perkantoran \\ Volume 8 Issue 1, January-June 2021. Pages 77-86}

Based on these observations and interviews, it can be said that the picture of the appearance of physical evidence such as outside and inside the building can be said to be quite good. However, improvements need to be made so that the image in terms of the appearance of the Library and Archives Office of North Central Timor Regency can increase and it is hoped that visitors will feel proud to can visit the Regional Library of North Central Timor Regency as a library for the border area with the State of Timor Leste.

\section{Reliability}

The factor of reliability or the ability to provide immediate, accurate, and satisfying services in this case visitors/users can immediately get access to information about collection services. This reliability factor is part of the ability of the staff or human resources of the organization to understand its main duties and responsibilities in providing maximum service, in this case, the Regional Library Service of Timor Tengah Utara Regency needs to understand the services provided so that if there are providers/service users who are needing assistance in accessing library collection services can be immediately assisted.

From the findings in the field, it was found that the employees or staff of the Regional Library Office of North Central Timor Regency were sufficiently aware of the service products in the Regional Library. This was evidenced by the results of an interview with one of the Regional Library visitors who said that "the staff at the Regional Library are quite familiar with collections. What we need, the collection books are arranged according to the discipline of each book collection title, including the disciplines of social and political science, economics and business, management, religion, and so on. This classification makes it very easy for us as visitors to find the desired book.

This indicates a good understanding by the staff of the Library Service of the service products provided by the Regional Library Service to visitors.

\section{Responsiveness}

One of the indicators in determining service is responsiveness. Responsiveness is the confidence of employees to assist customers in providing responsive services. In this case, the Regional Library Office of North Central Timor Regency has the availability of sufficient and representative collections or what visitors want / users other than that when needed by library visitors, library staff or staff immediately serve.

The results of observations in the field obtained that the staff of the Border District Library Service District. Timor Tengah Utara is very responsive to what library visitors need. District library service. North Central Timor is very caring and nimble in anticipating complaints needed by visitors. The human service system used in the Regional Library of North Central Timor Regency does not reduce the responsiveness of employees in meeting complaints or needs desired by library visitors.

\section{Assurance}

The guarantees referred to in this research include the knowledge, abilities, politeness, and trustworthiness of employees and staff; free from danger, risk, or doubt. In this case, there is a sense of security and comfort felt by visitors/users in the library. Library employees are very enthusiastic in providing services, visitors who come do not hesitate to ask questions and convey things you need to know if you have anything to say. 
The assurance indicator is very important to support the comfort and sense of security of visitors when visiting the regional library. The findings were obtained based on an interview with one of the visitors that the employees were very friendly, besides that the library was accompanied by a place to read and access books in the library, only the collection was still lacking a lot and up to date.

\section{Empathy}

An indicator of empathy is very important for every employee to understand the needs of the community, including the District Library Office. North Central Timor, employees need to have empathy, which includes the ease of making relationships, good communication, personal attention, and understanding the needs of visitors. Therefore, the attitude of staff employee relations with visitors/users will only be well-formed if there is a sense of empathy of the employees.

Results of interviews with employees of the Regional Library Office of the District. North Central Timor explained that "in improving regional library services in the border region we always add to the collection of reading materials and install internet networks to further improve the quality of blood library services. However, we admit that it is still not optimal where our library is still manual in finding books that are available for use. want to read in this case not using a digital indexation system "

From the overall indicators of the quality of the library services in the North Central Timor Regency, it can be concluded that the implementation of service quality in the Regional Library Service in the border area of North Central Timor Regency generally only implements 3 service systems, namely the Administration, Circulation and Reference service system because it still uses a manual indexation system.

\section{The satisfaction of Library Service Users in the Border Area of North Central Timor Regency}

The description of service user satisfaction variables is based on indicators, namely 1) Quality of products/services; 2) Emotions; and 3) The cost or convenience provided can be explained as follows:

\section{Product/service quality}

The satisfaction of service users will certainly be easily achieved if there is a quality product/service, in this case, the quality of the district library service, Kab. North Central Timor. As it is known, the quality of a product/service is a condition that shows the quality of library service products such as books and or other services related to the quality of products/services provided by the Regional Library of Timor Tengah Utara Regency.

The observation results show that the library services at the North Central Timor Regency Library facilities are equipped with free internet access to attract community visitors and also a mobile library that operates in remote areas in the North Central Timor Regency.

This is reinforced by the results of interviews with the Secretary of the Regional Library Office of North Central Timor Regency who said that in increasing literacy in reading interest several things had been done, namely the existence of a mobile library in the form of a car that provided various books to be read by people in the Kab. North Central Timor, in addition to increasing the number of visitors to Perputaraan, is equipped with internet facilities that can be 


\section{Jurnal Administrare: Jurnal Pemikiran Ilmiah dan Pendidikan Administrasi Perkantoran Volume 8 Issue 1, January-June 2021. Pages 77-86}

accessed by all visitors to the Perputaraan. This has attracted a lot of interest from visitors who want to come to the library. And also every year we increase the number of the latest book collections of various titles. In 2019 the Regional Library of North Central Timor Regency succeeded in obtaining the Community Satisfaction Index (IKM) with a value of 80.7 issued by an NGO in North Central Timor Regency. This value increases every year. All of the above has made the Regional Library of East Timor Regency North Central is getting better over time.

\section{Emotions}

The second indicator of service user satisfaction variables is an emotional indicator, in this case, a mental condition or feeling obtained by users of the Regional Library services during or after visiting the Regional Library of North Central Timor Regency.

Interviews with several visitors at the Perputaraan Daerah related to what visitors feel during and after visiting the Perputaraan can be concluded that all of them say it is quite good in terms of service and comfort at the Regional PerputASAN, it's just that it is necessary so that library services are added to make the Regional Library of Central Timor Regency. The North is getting better in the future.

\section{Cost or convenience provided}

The last indicator of service user satisfaction is the cost or convenience indicator provided, in this case, all forms of costs incurred by users of the Regional Library services or the convenience obtained when visiting the Regional Library of North Central Timor Regency which encourages someone to come to visit using the library service. Area.

From the results of observations and interviews conducted with visitors, data is obtained that in terms of accessing services at the Regional Library of North Central Timor Regency or visiting the Regional Office, there is no charge at all or there is no fee. Visitors register as members free of charge and may borrow books or read the book to your heart's content. As for the ease of providing services in the Regional Libraries, they still use a manual system, in this case, they have not used a digital system as implemented by the Regional Libraries in some developed cities so that the community or service users if they are looking for several books, will take a long time.

\section{Discussion}

\section{Regional Library Service Quality Kab. North Central Timor}

Regional Library is one of the libraries provided that is owned and managed by the district/city government as a tangible manifestation of the partisanship of local governments in developing human resources in border areas. Good regional libraries which have various conveniences and conveniences are certainly very possible to be carried out by the Government Regions in optimizing the excellence of Regional Libraries. The more sophisticated and better the Regional Libraries owned by the Regency/City Government, the more it indicates the Government's concern for knowledge and access to information of the community. The convenience and ease of access to various reference sources for regional libraries will be a stimulus for people to want to visit the Regional Libraries.

Service systems that are still limited to administrative, circulation, and reference service systems are certainly expected in the future there will be additional services as conveyed by 
Rahayuningsih (2007) states that there are at least 10 types of services, whereof the 10 types of library services, regional libraries only have 3 types. types of services, among these services, namely: Administration, information, research, recreation, circulation services, reference services, literary tracing, user guidance, literature analysis, and service statistics. Practically having only 3 types of services, the services provided can be said to be sufficient Also, the three systems used are based on manual problems, namely the lack of several collections which still need to be added and updated each year of book titles. The use of manual systems used in searches and others is a fundamental cause of lack of service. $n$ that can be given. Different if you use a digital indexation system, of course, it will also have implications for the various services that can be provided, such as Regional Libraries in developed regions or cities.

Furthermore, there are three main things in service quality, namely caring, serving, and satisfying customers (Akib, Guntur, \& Salam: 2016) where the best service in modern management is to prioritize caring for service users. (Saggaf, Salam, Kahar, \& Akib: 2014). In the business or private sector it is usually referred to as excellent service (Akib, Guntur, \& Salam: 2016).

Also, no national standards are regulating the regional public library service system related to the number of book collections. The system used and so on. As stated implicitly in Law no. 43 of 2007 concerning Libraries that the service system is adjusted to the capacity of the Regional Government. There will still be related matters that must be implemented by the regional public libraries that have been fulfilled by the North Central Timor Regency Library Service such as the operational car "Mobile Library" in reaching remote areas in North Central Timor District.

Therefore, the Regional Library of North Central Timor Regency as a Regional Library in the Border Region of the Republic of Indonesia needs to pay more attention through serious side-by-side with human resource development and literacy in the Border area where the most basic thing that is deemed not optimal from a Regional Library is the availability of books. Sufficient books are added with other facilities and infrastructure that are very lame with Regional libraries in other districts and cities. Also, the central government needs to pay attention to and provide reinforcement to local governments, in this case, the Regional Library Service in border areas for the sake of improving infrastructure for increasing human resources so that later the disparity in the quality of Regional Libraries in the City and the Border Area is not too far away.

Good service quality certainly pays attention to comprehensively both internally and externally the service itself and constantly makes corrections and evaluations on customer perceptions. As stated by Zeithaml, et al in (Nur \& Seran, 2020) defines that: "Service quality is an evaluation focus that reflects customer perceptions of service quality, namely evidence of appearance, reliability, responsiveness, assurance, and empathy."

Therefore, in facilitating the achievement of the service quality of the Regional Libraries in the border areas, it depends on how much value the perception can be reflected by the border community, in this case, the library visitors of the border areas of the District. North Central Timor, where the indicators in question are viewed from the elements, namely evidence of appearance, reliability, responsiveness, assurance, and empathy besides that the success of services also greatly depends on the alignment of abilities, attitudes, appearance, attention, actions, and responsibilities in their implementation. 


\section{Jurnal Administrare: Jurnal Pemikiran Ilmiah dan Pendidikan Administrasi Perkantoran Volume 8 Issue 1, January-June 2021. Pages 77-86}

\section{The satisfaction of Regional Library Service Users Kab. North Central Timor}

As a border area with other countries, of course, the role of the library in the border area of the North Central Timor Regency is very central in improving the quality of human resources in border communities. One way to find out the service or contribution of regional libraries is by analyzing the satisfaction of users of regional library services in this case in Kab. North Central Timor.

Border communities certainly have the same rights in accessing information amid the current development of information technology as urban communities. Therefore there is no other way for the central government and regional governments to give serious attention to improving the quality and system of library services for the North Central Timor Regency so that in the future the regional library service system can compete with other districts/cities. With the advancement of information technology, libraries in border areas can also implement a digital service system which in turn has implications for increasing the attractiveness of border communities.

With the satisfaction of users of Regional Library services in border areas, it is hoped that it will become the basic capital of local governments in improving the quality of human resources in border areas so that later the Human Development Index in border areas can be increased.

\section{CONCLUSION}

The quality of library services in border areas in the Regional Library Service of North Central Timor Regency in terms of physical appearance, reliability, responsiveness, empathy can be described quite well. The library service system in the border areas is still limited to administration, circulation, and reference service systems where the system still uses a manual system not based on digital indexation. Meanwhile, the satisfaction of library service users in the Border Region at the Regional Library Office of North Central Timor Regency is also quite good with the manual system used. With the addition of services, it is hoped that it will have implications for the quality of services which can increase the satisfaction of service users which in turn can increase human resources in border areas.

\section{REFERENCES}

Ahmad, M., \& Abawajy, J. H. (2014). Digital Library Service Quality Assessment Model. Procedia - Social and Behavioral Sciences. https://doi.org/10.1016/j.sbspro.2014.03.715

Baldonado, M., Chang, C. C. K., Gravano, L., \& Paepcke, A. (1997). The Stanford Digital Library metadata architectur. International Journal on Digital Libraries. https://doi.org/10.1007/s007990050008

Bates, D. W., \& Gawande, A. A. (2003). Improving Safety with Information Technology. New England Journal of Medicine. https://doi.org/10.1056/nejmsa020847

Hack-Polay, D. (2011). Digital Library. In Digitisation Perspectives. https://doi.org/10.1007/978-94-6091-299-3_10

Hassanain, M. A., \& Al Ashwal, N. (2005). An approach to assess fire safety requirements in library facilities. Facilities. https://doi.org/10.1108/02632770510588646 
Hull, D., Pettifer, S. R., \& Kell, D. B. (2008). Defrosting the digital library: Bibliographic tools for the next generation web. In PLoS Computational Biology. https://doi.org/10.1371/journal.pcbi.1000204

Ismail, I., \& Darwis, M. (2016). Efektivitas Pelayanan Perpustakaan Sekolah Bagi Siswa di SMK Negeri 1 Pare-Pare. Jurnal Office, 2(2), 215-220.

Lovasz, A. E., Lovasz, E.-C., \& Gruescu, C. M. (2014). Digital Library of Mechanisms. Procedia - Social and Behavioral Sciences. https://doi.org/10.1016/j.sbspro.2014.12.290

Maurya, R. N. (2011). Digital Library and Digitization. International Journal of Information Dissemination and Technology.

Miyashita, A. (1997). National Science Museum NII-Electronic Library Service. Bull. Natn. Sci. Mus. Tokyo.

Niswaty, R., Darwis, M., Andriani, D., Nasrullah, M., \& Salam, R. (2020). Fasilitas Perpustakaan Sebagai Media dalam Meningkatkan Minat Baca Siswa. Khizanah AlHikmah: Jurnal Ilmu Perpustakaan, Informasi, Dan Kearsipan, 8(1), 71-78.

Nur, M., \& Seran, M. S. B. (2020). Service Quality of Border Region Higher Education Libraries. Jurnal Ad'ministrare, 6(2), 145-152.

Reviewed, P., Council, T. F., \& Library, D. (2011). California Digital Library UC Office of the President. The International Journal of Digital Curation.

Sun, J., \& Yuan, B.-Z. (2012). Development and Characteristic of Digital Library as a Library Branch. IERI Procedia. https://doi.org/10.1016/j.ieri.2012.06.044

Taylor, S., \& Todd, P. A. (1995). Understanding information technology usage: A test of competing models. Information Systems Research. https://doi.org/10.1287/isre.6.2.144

Theng, Y., Khoo, A., \& Chan, M. (2011). Understanding Usability Issues in a Public Digital Library. In Encyclopedia of Digital Government. https://doi.org/10.4018/978-1-59140789-8.ch 242

Venkatesh, V., Morris, M. G., Davis, G. B., \& Davis, F. D. (2003). User acceptance of information technology: Toward a unified view. MIS Quarterly: Management Information Systems. https://doi.org/10.2307/30036540 
86 Jurnal Administrare: Jurnal Pemikiran Ilmiah dan Pendidikan Administrasi Perkantoran Volume 8 Issue 1, January-June 2021. Pages 77-86

This page is intentionally left blank 